УДК 62-868:532.542.001.24

\title{
СПОСОБ ВИБРОСТРУЙНОЙ ГИДРОДИНАМИЧЕСКОЙ ТЕХНОЛОГИИ СОХРАНЕНИЯ ТЕКУЧЕСТИ УГЛЕВОДОРОДНЫХ ТОПЛИВ И НЕФТЕПРОДУКТОВ В УСЛОВИЯХ НИЗКИХ ТЕМПЕРАТУР
}

\author{
Азин Антон Владимирович', \\ antonazin@niipmm.tsu.ru \\ Богданов Евгений Петрович², \\ epbogdanov@mail.ru \\ Пономарев Сергей Владимирович', \\ psv@niipmm.tsu.ru \\ Рикконен Сергей Владимирович', \\ rikk2@yandex.ru
Национальный исследовательский Томский государственный университет, Россия, 634050, г. Томск, пр. Ленина, 36.
2 Национальный исследовательский Томский политехнический университет, \\ Россия, 634050, г. Томск, пр. Ленина, 30.
}

\begin{abstract}
Актуальность работы обусловлена необходимостью создания энергоэффективного способа сохранения текучести углеводородного топлива в условиях низких температур, при температурах существенно ниже температуры застывания продукта. В условиях низких температур высоких широт Сибири и Арктики имеются проблемы с запуском энергетических установок, работающих на углеводородном топливе и маслах. Применяемые термические и химические методы сохранения текучести топлива, масла и охлаждающей жидкости не дают полной гарантии в оперативной подготовке к работе автономных объектов. Вибрационные технологии могут существенно изменить реологические свойства углеводородного топлива посредством создания высоких сдвиговых скоростей и гистерезисного нагрева нефтепродуктов. Процесс вибрационного создания высоких сдвиговых скоростей сплошной среды имеет затраты энергии в десятки раз меньше, чем термический метод сохранения текучести топлива.

Низкая теплопроводность углеводородного топлива способствует образованию возле внутренних стенок резервуаров застывшего топлива, которое является теплоизоляцией. При внесении внутрь резервуара механической вибрационной мощности топливо внутри данной системы будет достаточно жидким и готовым к применению по требованию.

Цель: создание методики расчета теплоизоляционного эффекта застывшего нефтепродукта, определение количества энергии, необходимой для поддержания топлива в жидком состоянии при разных температурах окружающей среды.

Методы: математический расчет перепада температур в системе «стенка резервуара - слой застывшего топлива» и экспериментальные исследования изменения реологических свойств нефтепродуктов под воздействием системы затопленного вибрирующего конфузора.
\end{abstract}

Результаты. Предложен инженерный метод расчета толщины застывшего топлива на внутренних стенках резервуара при отрицательных температурах окружающей среды и величины механической энергии, необходимой для сохранения текучести топлива.

Ключевые слова:

Жидкий, вязкость нефти, вибратор, сила, механическое воздействие.

\section{Введение}

В настоящее время Россия интенсифицировала работы по освоению Арктики и Антарктики. По многолетнему опыту освоения западной и восточной Сибири известны постоянные проблемы с применением углеводородного топлива и масел в условиях низких температур. Применение депрессаторов (химических реагентов, применяемых для снижения вязкости продукта) имеет ограниченный эффект из-за временного эффекта - после повторного нагрева топлива (при нагреве топлива в баках и резервуарах) свойства депрессатора пропадают. Немалая стоимость депрессаторов входит в стоимость топлива. Работники нефтяных и газовых месторождений, военные, гражданские жители круглосуточно применяют термический метод приведения застывшего топлива в жидкое состояние, что является дорогим, длительным и небезопасным способом. Следовательно, на практике ос- трой проблемой является сохранение текучести углеводородных топлив и масел в условиях низких температур [1].

Поэтому актуальной проблемой является разработка метода сохранения текучести топлив при температурах, существенно ниже температуры застывания продукта, который был бы относительно дешевым, безопасным и существенно сократил время подготовки автономных и стационарных объектов к работе.

\section{Постановка задачи}

В научных источниках [2-8] описано, что изменения реологических свойств углеводородных топлив можно достичь следующими способами: термическим, химическим или воздействием разнообразных физических полей. Причем, в зависимости от конкретного способа воздействия, затрачиваемая энергия будет разная. Например, термический 
способ сохранения текучести в десятки раз более энергозатратен, чем виброструйный гидродинамический способ.

Основной метод, распространенный во всем миpe, - термический способ сохранения текучести топлив. Этот способ существенно более энергозатратен из-за низкой теплопроводности и высокой теплоёмкости нефтепродуктов. Постоянная времени нагрева в этом методе по тем же причинам очень высокая, т. е. продукт долго нагревается и приходит в рабочее состояние. При повторном нагреве реологические свойства топлива ухудшаются из-за испарения легких фракций и, чтобы достичь первоначальных реологических свойств, необходимо нагревать топливо до более высокой температуры.

Для повышения тактико-технических характеристик стационарных и подвижных автономных объектов, работающих в условиях высоких широт, предлагается использовать принцип виброструйного гидродинамического сохранения текучести углеводородных топлив и масел. Технические устройства, создающие виброструйные гидродинамические затопленные струи, могут отличаться по способу преобразования электрической энергии в гидродинамическую энергию [3-11].

Этот принцип позволяет:

- за счет высоких сдвиговых скоростей сплошной среды разрушать надмолекулярную структуру нефтепродуктов, тем самым сохранять текучесть при температуре, намного ниже температуры застывания продукта;

- за счет потерь на трение при высоких сдвиговых скоростях производить нагрев нефтепродукта;

- существенно снижать испарение легких фракций за счет нагрева нефтепродукта изнутри массы сплошной среды;

- осуществлять нагрев топлива в 3-4 раза быстрее, чем при термическом нагреве;

- теоретически сокращать затраты энергии на разжижение и нагрев нефтепродукта в 30-100 раз по сравнению с термическим методом.

Течение охлажденных топливных жидкостей существенным образом отличается от ньютоновских жидкостей, что иллюстрирует рис. 1 [2].

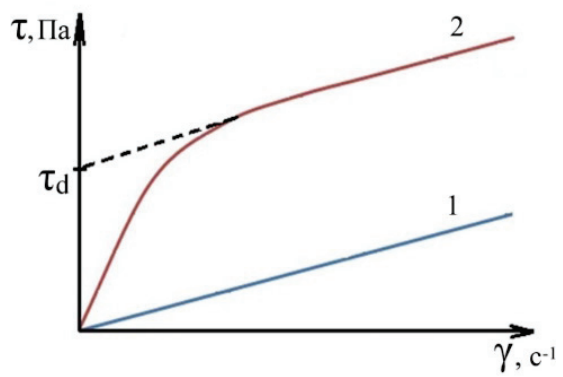

Pис. 1. Кривые течения ньютоновской (1) и неньютоновской (2) жидкостей

Fig 1. Flow curves of Newtonian (1) and non-Newtonian (2) fluids

Нелинейность зависимости напряжений сдвига $\tau$ и скорости сдвига $\gamma$ для неньютоновских жидко- стей (2) вызывает более высокие абсолютные значения показателей вязкости по сравнению с ньютоновскими жидкостями (1), что в большей степени проявляется в области малых скоростей. Эффективная вязкость таких жидкостей при малых скоростях во многом определяется величиной $\tau_{d}-$ предельным значением динамического напряжения сдвига. Кроме этого, многие неньютоновские жидкости, в том числе топливо, масло, сырая нефть, промывочные и цементные растворы, в определенных условиях способны образовывать структуру и терять вследствие этого свою текучесть.

Переход таких жидкостей из нетекучего в текучее состояние происходит при постепенном росте усилия. Одной из определяющих причин такого поведения неньютоновских жидкостей является присутствие в их составе структурообразующих компонент, находящихся во взвешенном состоянии. Для сырой нефти и углеводородных топлив, в соответствующих условиях, это кристаллы парафинов и смолы.

Течение высокопарафинистых нефтей удовлетворительно описывается уравнением Шведова-Бингама с использованием двух параметров: пластической вязкости $\mu_{p}$ и динамического напряжения сдвига $\tau_{d}$. Динамическое напряжение сдвига характеризует прочность структуры нефти в условиях непрерывной деформации:

$$
\mu_{e f}=\mu_{p}+\frac{\tau_{d}}{\gamma}
$$

где $\mu_{p}$ - пластическая вязкость, Па॰с; $\tau_{d}$ - динамическое напряжения сдвига, Па; $\gamma$ - скорость сдвига, $1 / \mathrm{c} ; \mu_{e f}$ - эффективная вязкость, Па.с.

Разнообразные воздействия физическими полями существенно изменяют величину динамического напряжения сдвига, и в меньшей степени пластическую вязкость [3-12].

При снижении температуры окружающей среды все углеводородные продукты изменяют свои реологические свойства: за счет образования устойчивой надмолекулярной парафиновой структуры резко увеличивается вязкость топлива и масла (рис. 2).
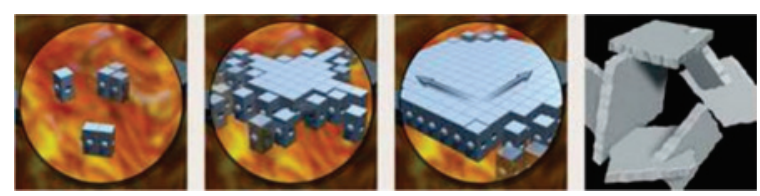

Pис.2. Механизм образования (застывания) парафиновой кристаллической (надмолекулярной) структуры нефтепродукта при снижении температуры [12]

Fig. 2. Mechanism of formation (solidification) of paraffinic crystalline (supramolecular) structure of oil product with temperature decrease [12]

Со временем за счет испарения легких фракций с открытых поверхностей углеводородного топлива в резервуарах, полимеризации, окисления и других химических реакций углеводородное топливо «стареет» - качество падает. 
Кроме этого, в холодную погоду все топлива и масла приобретают жесткую надмолекулярную структуру и прекращают течь по топливной системе, что приводит к невозможности пуска двигателей, работающих на углеводородном топливе (мазуте и солярке). Данная ситуация существенно снижает оперативность пуска энергетических установок или ведет к существенным затратам топлива на обогрев мазута, солярки и масла на уровне температуры подготовки к сжиганию. Ситуация усугубляется при наличии в топливе воды, которая может попасть в мазут или солярку во время транспортировки.

Основными теплофизическими свойствами мазута являются: вязкость, плотность, теплоемкость и теплопроводность.

Удельная теплоемкость мазутов при (20-100) ${ }^{\circ} \mathrm{C}$ составляет $1,74 \mathrm{\kappa Дж/кг.}{ }^{\circ} \mathrm{C}$.

Теплопроводность мазута весьма мала и составляет $(0,12-0,16) \mathrm{Bт} / \mathrm{s}^{\circ} \mathrm{C}$.

Вязкость зависит от температуры, давления и предварительной термической обработки топлива. Зависимость вязкости мазута М-100 от температуры показана на рис. 3.

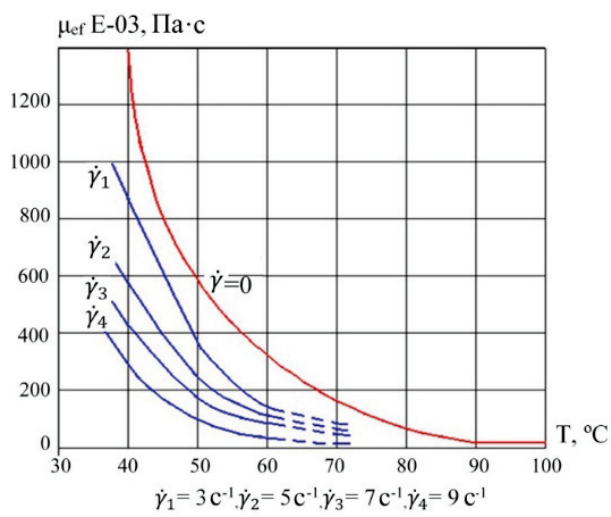

Puс. 3. Изменение эффективной вязкости мазута марки $M$ 100 в зависимости от температуры при разных сдвиговых скоростах

Fig. 3. Change of the M-100 oil fuel effective viscosity depending of temperature at different shear rates

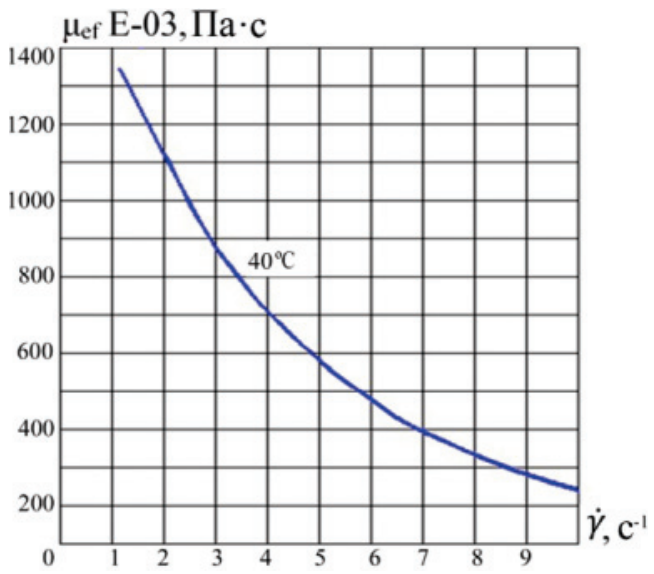

Pис. 4. Изменение вязкости мазута в зависилости от сдвиго вой скорости течения

Fig. 4. Change of fuel oil viscosity depending of the shear flow rate
Плотность мазута различных марок меняется в пределах $(0,95-1,06)$ т/ $\mathrm{M}^{3}$ (таблица).

таблица. Температурные характеристики мазута различных марок

Table. Temperature characteristics of the fuel oil of various grades

\begin{tabular}{|c|c|c|c|}
\hline $\begin{array}{c}\text { Марка } \\
\text { мазута } \\
\text { Fuel oil grade }\end{array}$ & $\begin{array}{c}\text { Температура } \\
\text { застывания } \\
\text { Pour point }\end{array}$ & $\begin{array}{c}\text { Tемпература слива } \\
\text { Discharge } \\
\text { temperature }\end{array}$ & $\begin{array}{c}\text { Температура } \\
\text { вспышки } \\
\text { Burst temperature }\end{array}$ \\
\cline { 2 - 4 } M-40 & \multicolumn{3}{|c|}{${ }^{\circ} \mathrm{C}$} \\
\hline M-60 & 25 & 25 & 90 \\
\hline M-100 & 25 & 40 & 100 \\
\hline TKM-16 & 38 & $40-50$ & 100 \\
\hline
\end{tabular}

За счет потерь на трение при высоких сдвиговых скоростях движения среды (топлива, масла) происходит гистерезисный нагрев и одновременно разрушение надмолекулярной структуры среды. При этом значения вязкости мазута можно сохранять на низком уровне даже при отрицательных температурах. Тепловые характеристики среды в этом процессе не участвуют, и значения теплопроводности не имеют значение, следовательно, требуется существенно меньше энергии, необходимой для достижения заданной вязкости, чем при нагреве.

На рис. 3, 4 показаны типичные кривые вязкости в зависимости от сдвиговых скоростей движения. Одних и тех же значений вязкости можно достичь и нагревом, и сдвиговой скоростью. С уменьшением температуры значения сдвиговых скоростей для достижения одной и той же вязкости должны быть выше.

\section{Численные результаты}

Низкая теплопроводность мазутов обуславливает особенности их застывания в цистернах при транспортировке. На рис. 5 показано распределение температуры мазута от стенки к оси котла цистерны, полученное опытным путем. Здесь кривая 1 характеризует распределение температуры мазута в цистерне через час после погрузки, кривые 2-5 - соответственно через 18, 40, 72 и 120 часов транспортировки мазута. Температура мазута при загрузке примерно $75^{\circ} \mathrm{C}$, а температура окружающей среды изменялась от -6 до $-2{ }^{\circ} \mathrm{C}$. Таким образом, даже при длительном остывании лишь тонкий пристеночный слой мазута имеет температуру, близкую к температуре наружной среды, а в центре цистерны температура мазута близка к температуре слива (рис. 5).

Расчет проводится в предположении, что резервуар имеет внутренний источник энергии.

Таким образом, даже при длительном остывании лишь тонкий пристеночный слой мазута имеет температуру, близкую к температуре наружной среды, а в центре котла цистерны температура мазута близка к температуре слива. При наличии небольшого по величине источника энергии внутри резервуара (цистерны) и обеспечении должной теплоизоляции большая часть топлива будет находится в жидком состоянии [14-23]. 
$\mathrm{T},{ }^{\circ} \mathrm{C}$

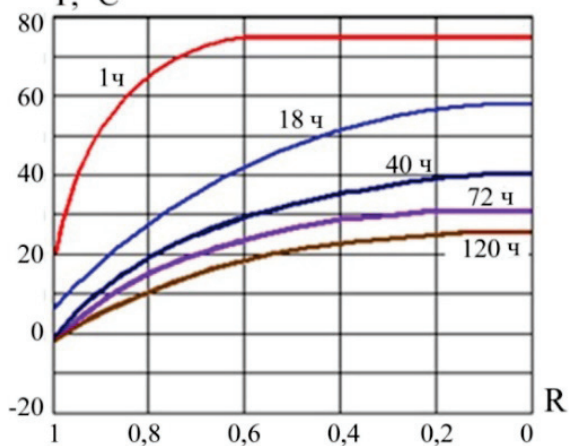

Pис. 5. Распределение температуры мазута от стенки к иентру иистерны. $R$ - расстояние от иентра резервуара до стенки

Fig. 5. Fuel oil temperature distribution from the wall to the center of the tank. Ris the distance from the center of the tank to the wall

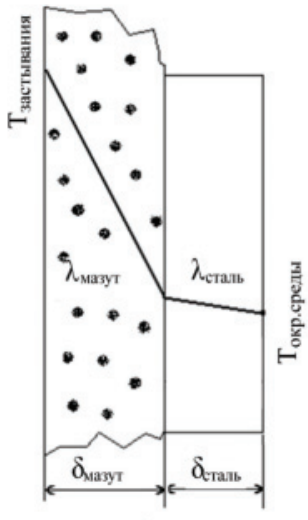

a)

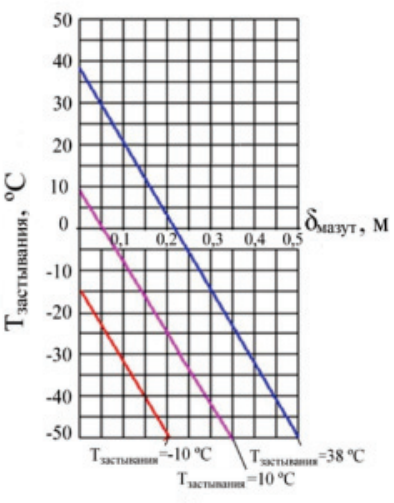

b)
Рис.6. Определение толщины застывщего мазута в зависимости от температуры окружающей среды и температу ры застывания мазута: а) схела теплового расчета; $b$ ) зависилость толщины структурированного мазута от телпературы среды

Fig. 6. Determination of the solidified fuel oil thickness, depending on the ambient temperature and the freezing temperature of fuel oil: a) scheme of thermal calculation; $b$ ) dependence of the thic kness of structured fuel oil on the temperature of the medium

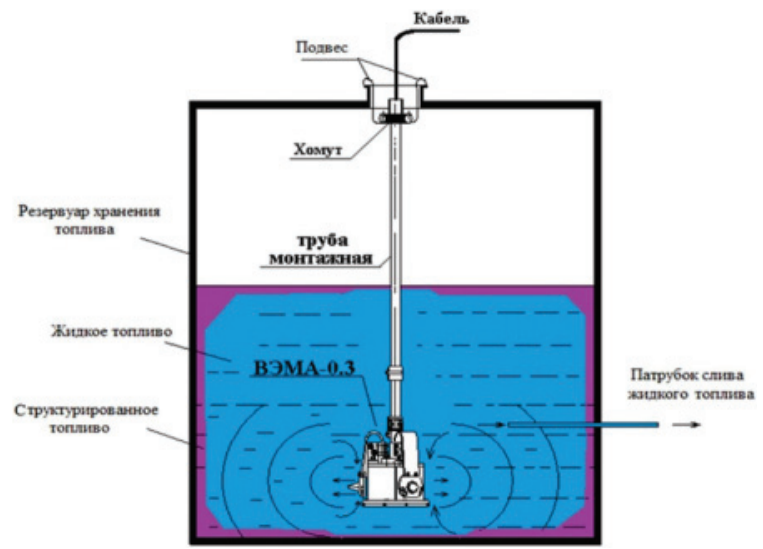

Pис. 7. Схела установки по поддержанию текучести топлива в условиях низких телператур с использованием виброструйного электромагнитного активатора ВЭМА- 0.3

Fig. 7. Installation scheme for maintaining fuel fluidity at low temperatures using VEMA-0.3 vibrating-jet electromagnetic activator
В настоящее время в технике имеется устройство, создающее высокие сдвиговые скорости в сплошной среде - виброструйный электромагнитный активатор ВЭМА-0.3, работающий на принципе виброструйного гидродинамического активатора.

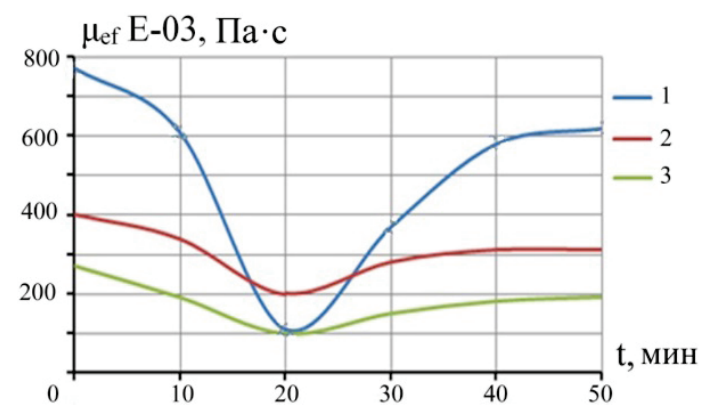

Pис. 8. Зависимость эффективной вязкости от времени виброструйного воздействия: 1 - нефть Останинского месторождения; 2 - нефть Южно-Табаганского месторождения; 3 - нефть Урланского месторождения

Fig. 8. Dependence of the effective viscosity on vibratory action time: 1 is the Ostaninskoe oil; 2 is the oil of the South Tabagan field; 3 is the oil from the Urmansky field

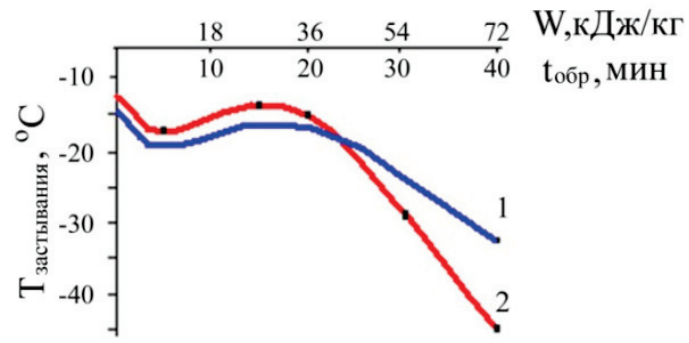

Pис.9. Влияние времени виброобработки на температуру застывания нефтей и мазута: 1 - нефть Таймурзинская; 2- мазут

Fig. 9. Influence of vibro-processing time on freezing point of the oil and fuel oil: 1 is the Taimurzinskaya oil; 2 is the fuel oil

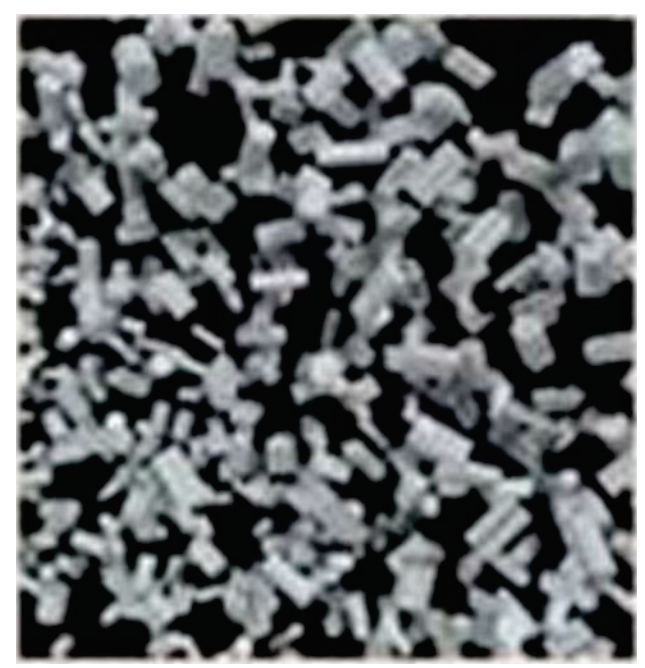

Рис. 10. Образование мелких дендритных кристаллов парафина, неспособных к кристаллизации после виброструйной обработки

Fig. 10. Formation of small dendritic paraffin crystals, incapable of crystallization after vibratory blasting 


\section{Выводы}

1. Необходимую вязкость и температуру топлива и масла можно получить не только энергозатратным термическим способом, но и организацией высоких сдвиговых скоростей топлива в зоне хранения.

2. Затраты энергии по сохранению текучести топлива и масла при использовании высоких сдвиговых скоростей топлива в зоне обработанного нефтепродукта при хранении в десятки раз меньше, чем при применении термического способа.

\section{СПИСОК ЛИТЕРАТУРЫ}

1. Рикконен С.В., Лоскутова Ю.В., Юдина Н.В. Результаты физико-химической обработки высокозастывающих нефтей // Перспективные материалы с иерархической структурой для новых технологий и надежных конструкций. - Томск: ИД ТГУ, 2018. - С. 633-634.

2. Structural properties of gelled Changqing waxy crude oil benefitted with nanocomposite pour point depressant / B. Yao, C. Li, F. Yang, Y. Zhang, Z. Xiao, G. Sun // Fuel. - 2016. - V. 184. P. 544-554.

3. The depressor ability of polyalkyl acrylate additives after ultrasonic treatment / G.I. Volkova, R.V. Anufriev, N.V. Yudina, 0.N. Chaykovskaya // Russian Physics Journal. - 2016. V. 59 (8). - P. 132-136.

4. Cherry E.M. Three dimensional velocity measurements in annular segments including the effects of upstream strut wake // International Journal of Heat and Fluid Flow. - 2010. - V. 31. P. $569-575$.

5. Viscosity of Liquids. Theory, Estimation, Experiment, and Data / D.S. Viswanath, T.K. Ghosh, D.H.L. Prasad, N.V.K. Dutt, K.Y. Rani. - Dordrecht, The Netherlands: Springer, 2007. $660 \mathrm{p}$.

6. Расчет гидравлических сопротивлений затопленного вибрирующего конфузора электромагнитного вибратора А.В. Азин, Е.П. Богданов, С.В. Пономарев, С.В. Рикконен // Известия Томского политехнического университета. Инжиниринг георесурсов - 2017. - Т. 328. - № 2. - С. 67-75.

7. Расчет энергетических параметров затопленного вибрирующего конфузора электромагнитного вибратора / А.В. Азин, Е.П. Богданов, С.В. Пономарев, С.В. Рикконен // Известия Томского политехнического университета. Инжиниринг георесурсов. - 2017. - Т. 328. - № 5. - С. 16-23.

8. Данекер В.А., Рикконен С.В. Приготовление и коррекция показателей бурового раствора технологией и оборудованием // Известия Томского политехнического университета. Инжиниринг георесурсов. - 2017. - Т. 328. - № 7. - С. 86-92.

9. Ткачев 0.А., Тугунов П.И. Сокращение потерь нефти при транспорте и хранении. - М.: Недра, 1988. - 116 с.

10. Shives M.R. Hydrodynamic Modeling, Optimization and Performance Assessment for Ducted and Non-ducted Tidal Turbines: thesis M.A.Sc: - B.Eng., 2011. 24 p.

11. Shina P.K., Das A.K., Majumdar B. Numerical Investigation of flow through Annular Diffusing Duct // International Journal of Engineering \& Technology. - 2011. - V. 11. - № 3. - P. 186-196.
3. Организацию высоких сдвиговых скоростей течения топлива в резервуарах можно осуществить применением маломощных виброструйных вибраторов разной конструкции.

4. При достаточной теплоизоляции резервуаров с учетом теплоизоляционных свойств структурированного углеводородного топлива поддержание топлива и масла в жидком состоянии можно осуществлять маломощными виброструйными вибраторами, работающими постоянно.

5. Величиной вязкости и температуры топлива и масла возможно управлять посредством времени работы вибратора.

12. Gant S., Stallard T. Modelling a tidal turbine in unsteady flow // Proc. Eighteenth International Offshore and Polar Engineering Conference. - Vancouver BC, Canada, 2008. - P. 473-479.

13. Dutt N.V.K., Prasad D.H.L. Representation of the Temperature Dependence of the Viscosity of Pure Liquids / Private Communication, Chemical Engineering Division. - Hyderabad: Indian Institute of Chemical Technology, 2004. - P. 128-136.

14. Keerthana R., Jamuna R.G. Flow analysis of annular diffusers // International Journal of Engineering Research and Applications. - 2012. - V. 2. - Iss. 3. - P. 2348-2351.

15. Karsten R., Swan A., Culina J. Assessment of arrays of in-stream tidal turbines in the Bay of Fundy. - 2013. URL: https:// doi.org/10.1098/rsta.2012.0189 (дата обращения: 10.02.2019).

16. The prediction of the hydrodynamic performance of marine current turbines / W. Batten, A. Bahaj, A. Molland, J. Chaplin // Renewable Energy. - 2008. - V. 33. - P. 1085-1096.

17. Sagar D., Paul A.R., Jain A. Experimental investigations of flow computational fluid dynamics investigation of turbulent separated flows in axisymmetric diffusers // International Journal of Engineering, Science and Technology. - 2011. - V. 3. - № 2. P. 104-109.

18. Shives M. Evaluation of discrete blade effects for ducted turbines using an actuator line CFD method. - Greater Victoria: University of Victoria, 2011. - $120 \mathrm{p}$.

19. Tao R., Xu X. Reducing the viscosity of crude oil by pulsed electric or magnetic field // Energy \& Fuels. - 2006. - V. 20. P. 2046-2051.

20. Loskutova Yu.V., Prozorova I.V., Yudina N.V. Improving the Structural-Rheological Properties of High-Paraffin Crude Oil Using Chemical Reagents and Vibrational Treatment // Chemistry and Technology of Fuels and Oils. - 2011. - V. 5. - P. 21-24.

21. Mal'tseva E.V., Bogoslovskii A.V., Yudina N.V. Application of the low-frequency vibratory method for determining the paraffin crystallization onset in dispersed petroleum systems // Russian Journal of Applied Chemistry. - 2012. - V. 85. - P. 751-754.

22. Данекер В.А. Расчет и конструирование электромагнитных преобразователей для активации жидких систем. - Томск: Изд-во Томского политехнического университета, 2018. $102 \mathrm{c.}$

23. Резонансные колебания с предельной амплитудой в вибрационом электромагнитном активаторе / А.Н. Гаврилин, Е.В. Боловин, А.С. Глазырин, С.Н. Кладиев, В.И. Полищук // Известия Томского политехнического университета. Инжиниринг георесурсов. - 2019. - Т. 330. - № 1. - С. 201-213. 


\section{Информация об авторах}

$\boldsymbol{A з и н} \boldsymbol{A}$.B., кандидат физико-математических наук, старший научный сотрудник Научно-исследовательского института прикладной математики и механики Национального исследовательского Томского государственного университета.

Богданов Е.П., кандидат технических наук, доцент Инженерной школы энергетики Национального исследовательского Томского политехнического университета.

Пономарев C.B., доктор физико-математических наук, старший научный сотрудник, заведующий отделом Научно-исследовательского института прикладной математики и механики Национального исследовательского Томского государственного университета.

Pикконен C.B., кандидат технических наук, старший научный сотрудник Научно-исследовательского института прикладной математики и механики Национального исследовательского Томского государственного университета. 
UDC 62-868:532.542.001.24

\title{
METHOD OF VIBRO-JET HYDRODYNAMIC TECHNOLOGY TO RETAIN THE FLUIDITY OF HYDROCARBON FUELS AND PETROLEUM PRODUCTS AT LOW TEMPERATURES
}

Anton V. Azin', antonazin@niipmm.tsu.ru

Evgeniy P. Bogdanov², epbogdanov@mail.ru

Sergey V. Ponomarev', psv@niipmm.tsu.ru

\author{
Sergey V. Rikkonen', \\ rikk2@yandex.ru \\ 1 Tomsk State University, \\ 36, Lenin Avenue, Tomsk, 634050, Russia. \\ 2 National Research Tomsk Polytechnic University, \\ 30, Lenin Avenue, Tomsk, 634050, Russia.
}

The relevance of the research is cased by the need to develop an energy-efficient way to maintain the fluidity of hydrocarbon fuels at low temperatures, at temperatures significantly lower the freezing point of the product. Under conditions of low temperatures of high latitudes of Siberia and Arctic, there are problems with the launch of power plants operating on hydrocarbon fuels and oils. Thermal and chemical methods used to preserve the fluidity of fuel, oil and coolant fluid do not provide a complete guarantee in operational preparation for operation of autonomous objects. Vibration technologies can significantly change the rheological properties of hydrocarbon fuels by creating high shear rates and hysteresis heating of petroleum products. The process of vibratory creation of high shear velocities in a continuous medium has energy costs ten times less than the thermal method for maintaining fuel flow. The low thermal conductivity of hydrocarbon fuel contributes to formation of solidified fuel near the inner walls of the tanks, which are the thermal insulation. Introducing a mechanical vibration power inside the tank, the fuel inside this system will be sufficiently liquid and ready for use on demand.

The main aim of the research is to create a method for calculating heat-insulating effect of a frozen petroleum product, to determine the amount of energy required to maintain the fuel in a liquid state at different ambient temperatures.

Methods: mathematical calculation of the temperature difference in the system "tank wall - layer of solidified fuel» and experimental studies of changes of rheological properties of petroleum products under the influence of a submerged vibrating confuser system.

Results. The authors have proposed the engineering method for calculating frozen fuel thickness on the inner walls of the tank at negative ambient temperatures and the amount of mechanical energy required to maintain fuel fluidity.

Key words:

Liquid, oil viscosity, vibrator, force, mechanical action.

\section{REFERENCES}

1. Rikkonen S.V., Loskutova Yu.V., Yudina N.V. Rezultaty fizikokhimicheskoy obrabotki vysokozastyvayushchikh neftey [The results of physico-chemical treatment of high-solidifying oils]. Perspektionye materialy s ierarkhicheskoy strukturoy dlya novykh tekkhnologiy i nadezhnykh konstruktsy [Non-conventional materials with hierarchy structure for new technologies and reliable constructions]. Tomsk, TGU Publ. house, 2018. pp. $633-634$.

2. Yao B., Li C., Yang F., Zhang Y., Xiao Z., Sun G. Structural properties of gelled Changqing waxy crude oil benefitted with nanocomposite pour point depressant. Fuel, 2016, vol. 184, pp. 544-554.

3. Volkova G.I., Anufriev R.V., Yudina N.V., Chaykovskaya 0.N. The depressor ability of polyalkyl acrylate additives after ultrasonic treatment. Russian Physics Journal, 2016, vol. 59 (8), pp. 132-136.

4. Cherry E.M. Three dimensional velocity measurements in annular segments including the effects of upstream strut wake. International Journal of Heat and Fluid Flow, 2010, vol. 31, pp. 569-575.

5. Viswanath D.S., Ghosh T.K., Prasad D.H.L., Dutt N.V.K., Rani K.Y. Viscosity of Liquids. Theory, Estimation, Experiment, and Data. Dordrecht, The Netherlands, Springer, 2007. 660 p.
6. Azin A.V., Bogdanov E.P., Ponomarev S.V., Rikkonen S.V. Calculation of hydraulic resistances of a submerged vibrating confuser of an electromagnetic vibrator. Bulletin of the Tomsk Polytechnic University. Geo assets Engineering, 2017, vol. 328, no. 2, pp. 67-75. In Rus.

7. Azin A.V., Bogdanov E.P., Ponomarev S.V., Rikkonen S.V. Calculation of energy parameters of submerged vibrating confuser of an electromagnetic vibrator. Bulletin of the Tomsk Polytechnic University. Geo assets Engineering, 2017, vol. 328, no. 5, pp. 16-23. In Rus.

8. Daneker V.A., Rikkonen S.V. Preparation and correction of drilling mud by technology and equipment of Vibro Jet Magnetic Activation. Bulletin of the Tomsk Polytechnic University. Geo assets Engineering, 2017, vol. 328, no. 7, pp. 86-92. In Rus.

9. Tkachev 0.A., Tugunov P.I. Sokrashchenie poter nefti pri transporte $i$ khranenii [Reducing oil losses at transport and storage]. Moscow, Nedra Publ., 1988. 116 p.

10. Shives M.R. Hydrodynamic Modeling, Optimization and Performance Assessment for Ducted and Non-ducted Tidal Turbines: thesis M.A.Sc: B.Eng., 2011. 24 p.

11. Shina P.K., Das A.K., Majumdar B. Numerical Investigation of flow through Annular Diffusing Duct. International Journal of Engineering \& Technology, 2011, vol. 11, no. 3, pp. 186-196. 
12. Gant S., Stallard T. Modelling a tidal turbine in unsteady flow. Proc. Eighteenth International Offshore and Polar Engineering Conference. Vancouver BC, Canada, 2008. pp. 473-479.

13. Dutt N.V.K., Prasad D.H.L. Representation of the Temperature Dependence of the Viscosity of Pure Liquids. Private Communication, Chemical Engineering Division. - Hyderabad, Indian Institute of Chemical Technology, 2004. pp. 128-136.

14. Keerthana R., Jamuna R.G. Flow analysis of annular diffusers. International Journal of Engineering Research and Applications, 2012, vol. 2, Iss. 3, pp. 2348-2351.

15. Karsten R., Swan A., Culina J. Assessment of arrays of in-stream tidal turbines in the Bay of Fundy. 2013. Available at: https://doi.org/10.1098/rsta.2012.0189 (accessed: 10 February 2019).

16. Batten W., Bahaj A., Molland A., Chaplin J. The prediction of the hydrodynamic performance of marine current turbines. Renewable Energy, 2008, vol. 33, pp. 1085-1096.

17. Sagar D., Paul A.R., Jain A. Experimental investigations of flow computational fluid dynamics investigation of turbulent separated flows in axisymmetric diffusers. International Journal of Engineering, Science and Technology, 2011, vol. 3, no. 2, pp. 104-109.

18. Shives M. Evaluation of discrete blade effects for ducted turbines using an actuator line CFD method. Greater Victoria, University of Victoria, 2011. $120 \mathrm{p}$.

\section{Information about the authors}

Anton V. Azin, Cand Sc., scientific associate, Tomsk State University.

Evgeniy P. Bogdanov, Cand Sc., associate professor, National Research Tomsk Polytechnic University.

Sergey V. Ponomarev, Dr. Sc., professor, Tomsk State University.

Sergey V. Rikkonen, Cand Sc., senior researcher, Tomsk State University.
19. Tao R., Xu X. Reducing the viscosity of crude oil by pulsed electric or magnetic field. Energy \& Fuels, 2006, vol. 20, pp. 2046-2051.

20. Loskutova Yu.V., Prozorova I.V., Yudina N.V. Improving the Structural-Rheological Properties of High-Paraffin Crude Oil Using Chemical Reagents and Vibrational Treatment. Chemistry and Technology of Fuels and Oils, 2011, vol. 5, pp. 21-24.

21. Mal'tseva E.V., Bogoslovskii A.V., Yudina N.V. Application of the low-frequency vibratory method for determining the paraffin crystallization onset in dispersed petroleum systems. Russian Journal of Applied Chemistry, 2012, vol. 85, pp. 751-754.

22. Daneker V.A. Raschet $i$ konstruirovanie elektromagnitnykh preobrazovateley dlya aktivatsii zhidkikh sistem [Calculation and design of electromagnetic transducers for activation of liquid systems]. Tomsk, Tomsk Polytechnic University Publ. house, 2018. $102 \mathrm{p}$.

23. Gavrilin A.N., Bolovin E.V., Glazyrin A.S., Kladiev S.N., Polishchuk V.I. Resonant oscillations with a limiting amplitude in a vibration electromagnetic activator. Bulletin of the Tomsk Polytechnic University. Geo Assets Engineering, 2019, vol. 330, no. 1, pp. 201-213. In Rus.

Received: 18 February 2019. 